\title{
RESPON PERTUMBUHAN DAN HASIL TANAMAN WORTEL (Daucus carota L.) AKIBAT PEMBERIAN URIN KELINCI
}

\author{
Kiki Zakiah', Wahid Erawan², Muna Rahmat ${ }^{2}$ \\ ${ }^{1)}$ Dosen Program Studi Agroteknologi Fakultas Pertanian Universitas \\ Garut \\ ${ }^{2)}$ Dosen Program Studi Agribisnis Fakultas Pertanian Universitas Garut \\ ${ }^{3)}$ Mahasiswa Program Studi Agroteknologi Fakultas Pertanian \\ Universitas Garut \\ E-mail :kikizakiah@uniga.ac.id
}

\begin{abstract}
ABSTRAK
Percobaan dilaksanakan di Kampung Barukai Kecamatan Cisurupan Kabupaten Garut dengan ketinggian 1100 meter di atas permukaan laut dengan nilai reaksi tanah 5,63. Percobaan dilaksanakan pada bulan Agustus sampai November 2017. Tujuan penelitian adalah mengetahui interaksi antara konsentrasi dan frekuensi aplikasi urin kelinci terhadap pertumbuhan dan hasil tanaman wortel. Metode yang digunakan dalam penelitian adalah eksperimental dengan menggunakan Rancangan Acak Kelompok (RAK) pola faktorial 4 x 3 dengan 3 kali ulangan. Faktor pertama konsentrasi $(\mathrm{m})$ terdiri dari empat taraf perlakuan, yaitu: $\mathrm{m}_{1}=10 \mathrm{ml} /$ liter air, $\mathrm{m}_{2}=20 \mathrm{ml} /$ liter air, $\mathrm{m}_{3}=30 \mathrm{ml} /$ liter air, $\mathrm{m}_{4}=40 \mathrm{ml} /$ liter air. Faktor kedua frekuensi aplikasi urin kelinci (r) terdiri dari tiga taraf perlakuan, yaitu: $r_{1}=2$ kali, $r_{2}=4$ kali, $r_{3}=6$ kali. Hasil penelitian menunjukan terjadi interaksi antara konsentrasi dan frekuensi aplikasi urin kelinci terhadap panjang buah pada $90 \mathrm{HST}$. Secara mandiri, konsentrasi urin kelinci $40 \mathrm{ml} / \mathrm{liter}$ air menunjukan pengaruh terbaik terhadap tinggi tanaman, bobot buah tanaman dan bobot tanaman per plot. Sementara frekuensi aplikasi urin kelinci sebanyak 6 kali menunjukan pengaruh terbaik pada bobot buah tanaman dan bobot buah per plot.
\end{abstract}

Kata kunci: Frekuensi aplikasi, Urin kelinci, Wortel

\section{ABSTRACT}

The experiment was conducted in Barukai village Cisurupan, Garut. The area's height is 1100 meters above sea level, with soil reaction 5.63. The experiment conducted from August to November 2017. The aim of the research was to find out the effect of various concentrations and frequency of rabbit urine application on growth and yield of carrot. The experiment used was Randomited Block Design (RAK) factorial with three replications. The first factor was concentrations of rabbit urine $(\mathrm{m})$ consists of four levels: $m_{1}=10 \mathrm{ml} / \mathrm{liter}$ water, $m_{2}=20 \mathrm{ml} /$ iter water, $m_{3}=30 \mathrm{ml} /$ liter water, $m_{4}=40 \mathrm{ml} /$ liter water. The second factor was frequency of rabbit urine application $(r)$ consists of three $: r_{1}=2$ times, $r_{2}=4$ times, $r_{3}=6$ times. The results of the study showed that was an interaction between various concentrations and frequency of rabbit urine application to length of fruit at 90 DAP. Independently, the concentration $40 \mathrm{ml} / \mathrm{liter}$ water shows the 
best effect on the height of the plant, weight of fruit and weight of fruit per plot. Meanwhile, frequency of rabbit urine 6 times gave the best result to weight of fruit and weight of fruit per plot.

Key words: Frequency application, Rabbit urine, Carrot

\section{PENDAHULUAN}

Wortel termasuk ke dalam tanaman hortikultura yang banyak dibudidayakan dan digemari oleh masyarakat Indonesia. Berdasarkan data Badan Pusat Statistik dan Direktorat Jenderal Hortikultura luas areal panen wortel nasional mencapai 29 ribu - 32 ribu ha. Teknik budidaya yang tepat dalam rangka meningkatkan produktivitas wortel nasional perlu diupayakan, mengingat peluang pasar wortel yang semakin luas dan beragam. Masyarakat Indonesia mengkonsumsi sayuran ini baik berupa umbi segar, umbi beku segar dan umbi muda segar (Badan Pusat Statistik dan Direktorat Jenderal Hortikultura, 2017).

Pertumbuhan dan produksi tanaman wortel ditentukan oleh unsur hara yang diserap oleh tanaman tersebut. Salah satu upaya dalam meningkatkan produksi tanaman adalah melalui penambahan unsur hara pada tanaman melalui pemupukan. Mengingat semakin jenuhnya unsur hara pada tanah akibat pemupukan kimia dan penggunaan pestisida kimia, maka alternatif lain yang dapat dilakukan adalah dengan pemberian pupuk organik.

Pupuk organik berdasarkan bentuknya terbagi menjadi dua, yaitu pupuk berbentuk padat dan cair. Pupuk organik cair adalah larutan yang sebagian besar atau seluruhnya terdiri atas bahan organik yang berasal dari sisa tanaman, kotoran hewan, dan kotoran manusia yang berbentuk padat dan mudah larut, serta berisi satu atau lebih pembawa unsur yang dibutuhkan tanaman (Hadisuwito, 2010). Pupuk organik cair memiliki kelebihan yaitu lebih efisien dalam transportasi dan pengaplikasiannya di lapangan bila dibandingkan dengan pupuk padat.

Salah satu pupuk organik cair yang dapat digunakan adalah pupuk yang berasal dari urin kelinci. Urin kelinci selain mudah didapat, juga murah dan mengandung unsur hara terutama nitrogen $(\mathrm{N})$. Unsur $\mathrm{N}$ diperlukan oleh tanaman untuk pembentukan bagian vegetatif tanaman, seperti daun, batang, dan akar serta 
berperan vital pada saat tanaman melakukan fotosintesa serta sebagai pembentuk klorofil.

Hasil penelitian Nugraheni dan Paiman (2010), menunjukan bahwa konsentrasi urin kelinci sebesar 3000 ppm memberikan pengaruh nyata berat segar tanaman, berat kering tanaman, berat kering daun, berat kering batang, dan berat kering akar. Frekuensi pemberian urin kelinci 9 kali berpengaruh pada berat kering tanaman, berat kering daun, berat kering batang dan berat kering akar.

\section{METODE PENELITIAN}

Percobaan dilaksanakan di Desa Cisurupan Kecamatan Cisurupan Kabupaten Garut dengan ketinggian tempat $1100 \mathrm{~m}$ dpl. Tanah yang digunakan merupakan Ordo Andisol dengan nilai reaksi tanah 5,63. Tipe curah hujan berdasarkan kriteria Schmidt and Ferguson (1951) adalah tipe curah hujan B, yaitu basah. Percobaan dilaksanakan dari bulan Agustus sampai November 2017.

Bahan yang digunakan dalam percobaan adalah benih wortel (Daucus carota L.), pupuk kandang ayam, EM4 dan Pupuk Organik Cair Urin Kelinci. Alat-alat yang digunakan dalam percobaan ini adalah cangkul, tugal, timbangan dan alat tulis.

Percobaan yang digunakan dalam penelitian ini adalah eksperimental dengan Rancangan Acak Kelompok (RAK) pola faktorial 4x3 dengan tiga kali ulangan. Faktor pertama konsentrasi urin kelinci $(m)$ dengan empat taraf yaitu $m_{1}=10$ $\mathrm{ml} /$ liter air; $\mathrm{m}_{2}=20 \mathrm{ml} /$ liter air; $\mathrm{m}_{3}=30 \mathrm{ml} /$ liter air; $\mathrm{m}_{4}=40 \mathrm{ml} /$ liter air. Faktor kedua frekuensi aplikasi (r) dengan 3 taraf, yaitu: $r_{1}=2$ kali; $r_{2}=4$ kali; $r_{3}=6$ kali. Terdapat 12 kombinasi taraf perlakuan, yang diulang 3 kali sehingga jumlah plot perlakuan yaitu 36 plot percobaan.

\section{HASIL DAN PEMBAHASAN}

\section{Tinggi Tanaman}

Hasil analisis ragam menunjukkan tidak terjadi interaksi antara konsentrasi dan frekuensi aplikasi urin kelinci terhadap tinggi tanaman wortel pada umur 60 HST. Pengaruh mandiri dari konsentrasi dan frekuensi aplikasi urin kelinci disajikan pada Tabel 1 . 
Tabel 1. Tinggi Tanaman Umur 30, 45 dan 60 HST

\begin{tabular}{lccc}
\hline & \multicolumn{3}{c}{ Rata-rata Tinggi Tanaman (cm) } \\
\cline { 2 - 4 } & $30 \mathrm{HST}$ & $45 \mathrm{HST}$ & $60 \mathrm{HST}$ \\
\hline Konsentrasi Urin Kelinci & $5.89 \mathrm{a}$ & $19.41 \mathrm{a}$ & $34.19 \mathrm{a}$ \\
$\mathrm{m} 1=10 \mathrm{ml} /$ liter air & $6.41 \mathrm{a}$ & $19.93 \mathrm{a}$ & $38.00 \mathrm{a}$ \\
$\mathrm{m} 2=20 \mathrm{ml} /$ liter air & $6.81 \mathrm{a}$ & $19.44 \mathrm{a}$ & $37.07 \mathrm{ab}$ \\
$\mathrm{m} 3=30 \mathrm{ml} /$ liter air & $6.63 \mathrm{a}$ & $20.30 \mathrm{a}$ & $41.30 \mathrm{~b}$ \\
$\mathrm{~m} 4=40 \mathrm{ml} /$ liter air & & & \\
\hline Frekuensi Aplikasi & $6.56 \mathrm{a}$ & $19.67 \mathrm{a}$ & $36.53 \mathrm{a}$ \\
$\mathrm{r} 1=2 \mathrm{kali}$ & $6.39 \mathrm{a}$ & $20.94 \mathrm{a}$ & $38.92 \mathrm{a}$ \\
$\mathrm{r} 2=4 \mathrm{kali}$ & $6.36 \mathrm{a}$ & $18.68 \mathrm{a}$ & $37.47 \mathrm{a}$ \\
$\mathrm{r} 3=6 \mathrm{kali}$ & &
\end{tabular}

Keterangan : Angka rata-rata yang diikuti huruf yang sama pada setiap kolom, tidak berbeda nyata menurut Uji Jarak Berganda Duncan pada taraf nyata $5 \%$.

Angka rata-rata yang tersaji pada Tabel 1 menunjukan bahwa konsentrasi pupuk organik cair urin kelinci berpengaruh nyata terhadap tinggi tanaman pada periode pengamatan 60 HST. Pengamatan pada 30 HST dan pengataman 45 HST menunjukkan taraf faktor $m_{1}$ tidak berbeda nyata dengan $m_{2}, m_{3}$ dan $m_{4}$. Pengataman 60 HST menunjukkan taraf faktor $m_{1}$ tidak berbeda nyata dengan $m_{2}$ dan $m_{3}$ tetapi berbeda nyata dengan $m_{4}$. Perlakuan yang memberikan nilai tinggi tanaman terbaik terdapat pada perlakuan $\mathrm{m}_{4}$ yaitu sebesar $41.30 \mathrm{~cm}$ pada $60 \mathrm{HST}$.

Pemberian pupuk organik cair urin kelinci $40 \mathrm{ml} /$ liter air dapat memacu pertumbuhan tanaman paling optimal dibandingkan dengan perlakuan lain. Hal ini diduga, karena unsur nitrogen $(\mathrm{N})$ yang terkandung di dalam pupuk organik cair urin kelinci diserap oleh akar dan digunakan untuk pertumbuhan secara keseluruhan, terutama pada batang, cabang, dan daun.

Efek mandiri faktor perlakuan aplikasi urin kelinci menunjukan pengaruh yang nyata terhadap tinggi tanaman, kecuali pada pengamatan 30 HST. Pengamatan 30 HST, 45 HST dan 60 HST menunjukkan taraf faktor $r_{1}$ tidak berbeda nyata dengan $r_{3}$ dan $r_{2}$.

Berdasarkan hasil penelitian Simamora (2013) dan Djafar (2011), bahwa urin kelinci juga mampu mendukung pertumbuhan vegetatif yaitu tinggi tanaman. Berdasarkan hasil analisis urin kelinci yang digunakan diketahui nilai $\mathrm{K}_{2} \mathrm{O}$ yang 
terdapat dalam urin tersebut sangatlah tinggi yaitu 2,70\%. Kalium berperan dalam melindungi tanaman agar tidak mudah rebah. Oleh sebab itu, dapat dipahami bahwa kenaikan tinggi tanaman wortel tersebut salah satunya dipengaruhi oleh urin kelinci tersebut.

\section{Diameter Batang}

Hasil analisis ragam menunjukkan tidak terjadi interaksi antara konsentrasi dan frekuensi aplikasi urin kelinci terhadap jumlah daun wortel, namun secara mandiri terjadi perbedaan yang nyata pada taraf perlakuan. Hasil analisis selanjutnya disajikan pada Tabel 2.

Tabel 2. Diameter Batang Umur 90 HST

\begin{tabular}{ll}
\hline \multicolumn{1}{c}{ Perlakuan } & Rata-rata Diameter Batang $90 \mathrm{HST}\left(\mathrm{cm}^{2}\right)$ \\
\hline Konsentrasi Urin Kelinci & $2.96 \mathrm{a}$ \\
$\mathrm{m} 1=10 \mathrm{ml} /$ liter air & $3.02 \mathrm{a}$ \\
$\mathrm{m} 2=20 \mathrm{ml} /$ liter air & $3.09 \mathrm{a}$ \\
$\mathrm{m} 4=40 \mathrm{ml} /$ liter air & $3.16 \mathrm{a}$ \\
\hline Frekuensi Aplikasi & \\
$\mathrm{r} 1=2 \mathrm{kali}$ & $3.10 \mathrm{a}$ \\
$\mathrm{r} 2=4 \mathrm{kali}$ & $2.98 \mathrm{a}$ \\
$\mathrm{r} 3=6 \mathrm{kali}$ & $3.09 \mathrm{a}$
\end{tabular}

Keterangan : Angka rata-rata yang diikuti huruf yang sama pada setiap kolom, tidak berbeda nyata menurut Uji Jarak Berganda Duncan pada taraf nyata $5 \%$.

Angka rata-rata yang tersaji pada Tabel 2 menunjukan bahwa konsentrasi pupuk organik cair urin kelinci tidak berpengaruh nyata terhadap diameter batang tanaman pada periode pengamatan $90 \mathrm{HST}$ menunjukkan taraf faktor $\mathrm{m}_{1}$ berbeda nyata dengan $\mathrm{m}_{2}, \mathrm{~m}_{3}$ dan $\mathrm{m}_{4}$. Hal ini disebabkan kandungan unsur hara pada pupuk cair urin kelinci kurang memenuhi kebutuhan tanaman sehingga diameter pada wortel pada setiap perlakuan tidak berbeda nyata. 
Efek mandiri faktor perlakuan aplikasi urin kelinci menunjukan tidak berpengaruh nyata terhadap diameter batang pada setiap periode pengamatan. Pengamatan 90 HST taraf faktor $r_{1}$ tidak berbeda nyata dengan $r_{2}$ dan $r_{3}$. Hal tersebut disebabkan oleh faktor cuaca yang dapat menyebabkan unsur hara mengalami denitrifikasi, sehingga berbagai frekuensi aplikasi tidak berbeda nyata. Jumin (2005) menyatakan suhu akan mempengaruhi proses fisiologis tanaman dalam hal pertumbuhan tanaman jika suhu tinggi dan kelembaban rendah menyebabkan terhambatnya penyerapan unsur hara karena transpirasi meningkat dan proses fotosintesis terhambat. Suhu udara yang terlalu tinggi akan menyebabkan umbi kecil dan warnanya pucat, sebaliknya bila suhu udara terlalu rendah umbi yang terbentuk menjadi panjang dan kecil (Rukmana, 2007).

\section{Bobot Buah Per Plot}

Hasil analisis ragam menunjukkan tidak terjadi interaksi antara konsentrasi dan frekuensi aplikasi urin kelinci terhadap jumlah daun wortel, namun secara mandiri terjadi perbedaan yang nyata pada taraf perlakuan. Hasil analisis selanjutnya disajikan pada Tabel 3.

Tabel 3. Bobot Buah Perplot Umur 90 HST

\begin{tabular}{ll}
\hline \multicolumn{1}{c}{ Perlakuan } & Rata-rata per plot 90 HST (kilogram) \\
\hline Konsentrasi Urin Kelinci & \\
$\mathrm{m} 1=10 \mathrm{ml} /$ liter air & $2.21 \mathrm{a}$ \\
$\mathrm{m} 2=20 \mathrm{ml} /$ liter air & $2.74 \mathrm{ab}$ \\
$\mathrm{m} 3=30 \mathrm{ml} /$ liter air & $2.34 \mathrm{bc}$ \\
$\mathrm{m} 4=40 \mathrm{ml} /$ liter air & $2.97 \mathrm{c}$ \\
\hline Frekuensi Aplikasi & \\
$\mathrm{r} 1=2 \mathrm{kali}$ & $2.23 \mathrm{a}$ \\
$\mathrm{r} 2=4 \mathrm{kali}$ & $2.83 \mathrm{~b}$ \\
$\mathrm{r} 3=6 \mathrm{kali}$ & $2.63 \mathrm{ab}$
\end{tabular}

Keterangan : Angka rata-rata yang diikuti huruf yang sama pada setiap kolom, tidak berbeda nyata menurut Uji Jarak Berganda Duncan pada taraf nyata $5 \%$.

Angka rata-rata yang tersaji pada Tabel 3 menunjukan bahwa konsentrasi pupuk organik cair urin kelinci berpengaruh nyata bobot buah per plot pada periode 
pengamatan $90 \mathrm{HST}$. Taraf faktor $\mathrm{m}_{1}$ tidak berbeda nyata dengan $\mathrm{m}_{2}$ tetapi berbeda nyata dengan $m_{3}$ dan $m_{4}$. Nilai bobot buah per plot yang paling tinggi ditunjukkan oleh perlakuan $\mathrm{m}_{4}$ atau setara dengan $40 \mathrm{ml} /$ liter air. Hal tersebut dikarenakan unsur hara yang cukup sehingga dapat merangsang pertumbuhan vegetatif termasuk pembentukkan umbi pada wortel.

Efek mandiri faktor perlakuan aplikasi urin kelinci menunjukan berpengaruh nyata terhadap bobot buah per plot. Pengamatan 90 HST menunjukkan taraf faktor $r_{1}$ tidak berbeda nyata dengan $r_{3}$ tetapi berbeda nyata dengan $r_{2}$. Frekuensi aplikasi urin kelinci yang paling baik ditunjukkan oleh perlakuan $r_{2}$ atau sebanyak 4 kali aplikasi dan $r_{3}$ atau sebanyak 6 kali aplikasi. Hal ini disebabkan oleh kandungan unsur hara yang terdapat dalam urin kelinci salah satunya yaitu unsur kalium $(\mathrm{K})$ dengan kandungan yang cukup tinggi dibanding unsur lainnya. Unsur hara $\mathrm{K}$ berperan dalam pembentukkan karbohidrat, dengan meningkatnya karbohidrat yang dihasilkan maka dapat meningkatkan penambahan bobot ubi wortel.

Hasil bobot ubi per plot selain dipengaruhi oleh hasil ubi per tanaman juga dipengaruhi oleh jumlah populasinya, dimana pada jarak antar barisan yang rapat populasi lebih banyak (Sumpena dan Irni, 2005). Penggunaan pupuk organik memegang peranan penting dalam memacu pertumbuhan vegetatif, demikian juga terhadap ubi (Marpaung, 2011).

\section{KESIMPULAN}

Berdasarkan hasil penelitian yang telah dilakukan dapat disimpulkan bahwa secara mandiri, konsentrasi urin kelinci 30 dan $40 \mathrm{ml} /$ liter air menunjukan pengaruh terbaik terhadap tinggi tanaman pada 60 HST dan bobot buah per plot. Sementara frekuensi aplikasi urin kelinci sebanyak 6 kali menunjukan pengaruh terbaik terhadap bobot buah per plot. Sementara itu, berdasarkan hasil percobaan, baik konsentrasi maupun frekuensi pemberian urin kelinci, tidak berbeda nyata terhadap diameter buah.

\section{DAFTAR PUSTAKA}


Badan Pusat Statistik dan Direktorat Jenderal Tanaman Pangan. 2017. Jakarta. http://www.pertanian.go.id/ap pages/mod/datahorti. Diakses pada tanggal 20 Maret 2018.

Hadisuwito, S. 2010. Membuat Pupuk Kompos Cair. PT. Agro Media Pusaka. Jakarta.

Jumin, Hasan Basri. 2005. Dasar-dasar Agronomi. Rajawali Press. Jakarta.Kusnendar. 2017. Pupuk Organik Dari Kotoran dan Urin Kelinci. http://www.kusnendar.web.id/2013/06/pupuk-organik-dari-kotoran-danurine-kelinci.html. diakses pada tanggal 18 Mei 2017.

Marpaung, L. 2001. Pengaruh Pupuk Kandang dan Cara Bertanam Terhadap Produksi Ubi Wortel. Buletin Penelitian Hortikultura Badan Penelitian dan Pengembangan Pertanian Departemen Pertanian.

Nugraheni, Erika Dewi dan Paiman. 2010. Pengaruh Konsentrasi dan Frekuensi Pemberian Pupuk Urin Kelinci Terhadap Pertumbuhan dan Hasil Tomat (Lycopersicum Esculentum Mill). Fakultas Pertanian, Universitas PGRI Yogyakarta.

Rukmana, R., 2007. Bertanam Petsai dan Sawi. Kanisius, Yogyakarta. Hal: 11-35.

Simamora, A.L.B., Toga Simanungkalit, Jonis Ginting. 2014. Respons Pertumbuhan dan Produksi Bawang Merah (Allium ascalonicum L.) Terhadap Pemberian Vermikompos dan Urine Kelinci. J Agroekoteknologi 2(2):533-546.

Sumpena U dan Irni M. 2005. Pengaruh Dosis Pupuk Organik Kascing dan Jarak Tanam Terhadap Pertumbuhan dan Hasil Wortel (Daucus carota L.). Jurnal Agrivigor, Vol.5(1):26-33. 